\title{
DE STUDIE VOOR APOTHEKER IN NEDERLAND.*
}

\section{Inleiding.}

In Nederland is bij de wet op de artsenijbereidkunst de aflevering van geneesmiddelen in handen gelegd van academisch gevormde apothekers en is slechts bij wijze van noodmaatregel ook in bepaalde gevallen aan artsen toegestaan.

De studie in de pharmacie vindt plaats aan vier universiteiten, gevestigd in de steden Amsterdam, Groningen, Leiden en Utrecht. Het

Is het verantwoord om voor diegenen, die in een apotheek werkzaam willen zijn een dergelijk breed ougezette en langdurige studie vereist te stellen?

studieprogramma aan deze universiteiten is niet wezenlijk verschillend; slechts in bepaalde details wijkt de ene opleiding van de andere af.

In het hierna volgende zal een globaal overzicht van het studieprogramma gegeven worden, waardoor een beeld gevormd zal kunnen worden van de positie, die de apotheker in Nederland inneemt.

2. Studie in de pharmacie.

$\mathrm{Na}$ het beeindigen van de middelbare schoolopleiding vangt de universitaire studie aan, die in drie perioden is in te delen:

1. De studie tot het candidaatsexamen pharmacie;

2. De studie tot het doctoraalexamen pharmacie;

3. De studie tot het apothekersexamen.

\section{1. Candidaatsexamen.}

De studie tot het candidaatsexamen omvat de vakken scheikunde, plantkunde en natuurkunde.

- Die skrywer van hierdie artikel het 'n benoeming as hoof van die departement Farmasie aan die P.U. vir C.H.O. aanvaar.

As die leser 'n vergelyking sou wil tref tussen opleiding van Aptekers in Nederland en alhier, dan moet hy in gedagte hou dat dergelike opleidings in alle lande verskil en dat die in Nederland bekende verskil van "Apothekers' en "Drogisten" by ons nie bestaan nie. Die opleiding vir "Drogiste" in Nederland is minder intensief en minder ekstensief as die vir "Apothekers".Die Hoof redakteur. 
Daartoe worden de volgende colleges gegeven:

SCHEIKUNDE: analytische scheikunde; de grondbeginselen van de analytische scheikunde.

anorganische scheikunde; behalve behandeling van de verbindingen volgens het periodieke systeem, ook phasenleer en dergelijke.

organische scheikunde; algemeen college over aliphatische, aromatische en heterocyclische verbindingen.

physische scheikunde; leer der reactiesnelheden en -evenwichten, colloidchemie, photochemie, thermochemie en electrochemi. röntgenanalyse van kristallen; röntgenstralenafbuiging door kristalroosters (aan enige universiteiten).

chemische binding; theorie over stabiliteit, vorming en chemische en physische eigenschappen van de verbindingen (aan enige universiteiten).

PLANTKUNDE: plantensystematiek; algemeen college over de systematiek van lagere en hogere planten.

plantenphysiologie; leer van de levensverrichtingen van de plant. plantenanatomie en cytologie; structuur en celleer van de planten, daarbij aansluitend ook de crfelijkheidsleer.

NATUURKUNDE: algemene natuurkunde; speciaal de physische meetmethodes.

atoom- en kernphysica; inleiding in de physica van de atomen en de atoomkernen.

WISKUNDE: differentiaal- en integraalrekening; inleidend college.

MINERALOGIE: kristallographie; onderzoek en beschrijving van kristallen (aan enige universiteiten).

kristaloptiek; lichtbreking door kristallen (aan enige universiteiten).

DIERKUNDE: algemene cytologie en histologie; celleer en weefselleer (aan enige universiteiten).

anatomie en physiologie van de mens; (aan enige universiteiten).

Een aantal practica zijn voorts vereist:

Analytische en anorganische scheikunde; qualitatieve en quantitatieve analyse van anorganische verbindingen; tijdsduur ca. 1 jaar.

Organische scheikunde; bereiding van 20-30 organische verbindingen; tijdsduur ca. 1 jaar. 
Plantkunde; plantenanatomie en plantensystematiek; tijdsduur 2 jaar, $\frac{1}{2}$ dag per week; voor deze practica wordt een microscoop gebruikt.

Natuurkunde; 15-18 proeven op het gebied van geluid, licht, warmte en electriciteit; tijdsduur 1 jaar, $\frac{1}{2}$ dag per week.

Mineralogie; kristallographie gedurende $\frac{1}{4}$ jaar, $\frac{1}{2}$ dag per week, kristaloptiek gedurende $\frac{1}{2}$ jaar, $\frac{1}{2}$ dag per week (aan enige universiteiten).

Dierkunde; histologie en microscopische anatomie, gedurende 3 weken (aan enige universiteiten).

$\mathrm{Na}$ deze practica te hebben gevolgd, worden over de verschillende vakken tentamina afgelegd bij de betreffende docent. Daarna wordt het candidaatsexamen afgenomen. De totale studietijd tot het candidaatsexamen bedraagt ca. $3 \frac{1}{2}$ jaar.

In deze periode wordt tevens een aanvang gemaakt met het practisch werk in de apotheek, nadat een cursus gevolgd is in elementaire pharmaceutische begrippen.

\section{2. Doctoraalexamen.}

$\mathrm{Na}$ met goed gevolg het candidaatsexamen te hebben afgelegd, is de toegang geopend tot de studie voor hete doctoraalexamen. Hiervoor is vereist de studie in de hoofdvakken:

pharmaceutische chemie en toegrepaste analyse;

pharmacognosie en galenica,

terwijl bovendien een aantal verplichte bijvakken moeten worden bestudeerd. Deze bijvakken zijn verschillend voor de diverse universiteiten; in Utrecht zijn de verplichte bijvakken: toxicologie, levensmiddelenleer en microbiologie.

Voorts worden nog twee bijvakken gekozen. De keuze hiervan hangt af van de persoonlijke interesse of van het beroep, dat men na de studie uitoefenen wil. De keuze van deze bijvakken kan uit een groot aantal geschieden, waarvan de belangrijkste zijn: analytische chemie, biochemie, klinische chemie, levensmiddelenleer, pharmaceutische chemie, toxicologie, galenica, microbiologie, pharmacologie.

Voor de studie in de hoofdvakken worden gedurende drie jaar colleges gegeven; gemiddeld negen uur per week. Bovendien worden een aantal practica gevolgd. 
Voor de pharmaceutische chemie wordt gedurende $1 \frac{1}{2}-2$ jaar de qualitatieve en quantitatieve analyse uitgevoerd van anorganische en organische geneesmiddelen, alsmede mengsels van elke aard.

Voor de pharmacognosie wordt gedurende 2 jaar, $\frac{1}{2}$ dag per week de anatomie van pharmaceutisch belangrijke planten microscopisch bestudeerd, terwijl voor de galenica gedurende enige maanden de waardebepaling van de geneeskrachtige planten wordt uitgevoerd.

Van de verplichte bijvakken houdt toxicologie het uitvoeren van qualitatieve en quantitatieve analyse van vergiften in; de tijdsduur hiervoor is 1 th -3 maanden.

Voor levensmiddelenleer wordt het chemisch en physisch onderzoek van de beiangrijkste levensmiddelen gedurende 1-1 $\frac{1}{2}$ maand uitgevoerd. Voor microbiologie wordt gedurende 7-8 weken de isolatie, identificatie en telling ván bacteriën, schimmels en gisten bestudeerd en tevens serologische reacties uitgevoerd.

Voor de twee bijvakken naar eigen keuze wordt voor elk 3-6 maanden gewerkt. De keuze van de bijvakken moet aan een goedkeuring van de faculteit worden onderwarpen. In zoverre de keuze valt op bijvakken, die reeds verplicht gevolgd zijn, houdt het werk hiervoor in, dat een voortgezet onderzoek tot verdieping in deze materie leidt. Tijdens deze periode wordt ook een literatuurstudie over een gegeven onderwerp gemaakt en hierover een scriptie ingeleverd.

Ongeveer $3 \frac{1}{2}$ jaar na het candidaatsexamen wordt het doctoraalexamen afgelegd. Na dit eksamen kan de universitaire studie eventueel afgesloten worden met een promotie. Een enkele maal wordt dit gedaan vóór het apothekersexamen te hebben afgelegd, doorgaans echter daarna.

\section{3. Apothekersexamen.}

Het apothekersexamen is in tegenstelling met het candidaatsexamen en het doctoraalexamen in hoofdzaak een practisch examen.

In Groningen en Utrecht is dit examen gesplitst in twee gedeelten. Voor dit examen wordt geexamineerd in toegepaste analytische scheikunde, recepteerkunde en plantkunde, waarbij de examenstof geheel in overeenstemming is met de practijk van de apotheek. $\mathrm{Na}$ een voorbereiding van ongeveer één jaar kan deze eindpaal worden bereikt.

\section{De taak van de apotheker.}

$\mathrm{Na}$ een studie van 8-9 jaar wordt in Nederland het apothekersdiploma behaald. Door de uitgebreidheid van de studie heeft de pharmaceu- 
tische student de mogelijkheid om zich tijdens zijn studie te specialiseren in vele richtingen, die na de beeindiging van de studie aanleiding kunnen zijn tot het aanvaarden van een functie in de maatschappij buiten de apotheek.

Direct rijst daarbij de vraag of het verantwoord is om voor diegenen, die in een apotheek werkzaam willen zijn een dergelijke breed opgezette en langdurige studie vereist te stellen. Om deze vraag te kunnen beantwoorden is het noodzakelijk eerst de taak van de apotheker duidelijk to maken.

De apotheker heeft tot taak te zorgen voor de geneesmiddelenvoorziening van de zieke mens op een wijze, die de beste waarborgen biedt, dat geen vergissingen plaats vinden allereerst, terwijl de bereiding en de toebereiding van de geneesmiddelen op wetenschappelijke basis geschieden. Daarnaast dient de apotheker door het geven van adviezen en inlichtingen de deskundige te zijn op een gebied, dat én door de medicuspracticus én door de chemicus slechts voor een gedeelte kan worden beheerst.

Vooral de controlerende en de adviserende taak van de apotheker zijn belangrijke onderdelen in de uitoefening van het beroep. De controlerende taak is zeer toegenomen, sinds de apotheker de bereiding van vele geneesmiddelen niet meer op economisch verantwoorde wijze zelf kan uitvoeren, maar dit over moet laten aan de industrieën. Gezien het enorme aantal van geneesmiddelen van chemische en biologische herkomst, is een zeer uitgebreide kennis, zowel van de chemie als van de botanie resp. zoölogie, noodzakelijk. Deze kennis moet speciaal in de analytische richting zijn uitgebreid. De noodzaak van een contrôle van de geneesmiddelen blijkt uit de ervaring, dat ongeveer $10 \%$ van de door de diverse industriëen geleverde geneesmiddelen niet blijken te voldoen aan de wettelijk vastgestelde eisen van zuiverheid, terwijl dikwijls producten onder een verkeerde naam worden afgeleverd.

De adviserende taak van de apotheker is tweeledigr. In de eers te plaats zal de apotheker samenwerkend met de arts deze door zijn kennis tot steun kunnen zijn. Het is voor de practiserend arts vrijwel ondoenlik om bij de uitoefening van zijn practijk de vorderingen der medische wetenschap in zijn gehele omvang te blijven volgen. Speciaal in de geneesmiddelenvoorziening laat de arts zich maar al te dikwijls leiden door de reclame, die de industrie voor haar producten makt; een voorlichting, fifelechter allerminst objectief kan worden genoemd. Op dit punt moet - de defotfielfer'de objectieve deskundige kunnen zijn. 
In de tweede plaats zai de apotheker de mensen moeten kunnen adviseren over geneesmiddelen. Hij zal de zieke mens moeten verwijzen naar de arts, omdat deze beoordelen kan welke behandeling de patient nodig heeft. De apotheker zal echter de contrôle moeten bezitten over het geneesmiddelengebruik van de mensen. In landen waar de mensen alle geneesmiddelen zichzelf kunnen verschaffen, ontstaan uitwassen, die een gevaar voor de volksgezondheid zijn. Zo is onlangs nog zeer ernstig gewaarschuwd tegen het ongecontroleerd gebruik van antibiotica, waardoor in die landen, waar deze voor de therapie zo belangrijke verbindindingen zonder enige restrictie worden verstrekt, het gevaar van het ontstaan van resistente bacteriestammen als een zeer ernstig gevaar voor de volksgezondheid wordt onderkend.

De bereidende taak van de apotheker is in vergelijking met het verleden van veel geringer omvang geworden. Het bereiden van geneesmiddelen in de diverse toedieningsvormen vereist echter een goede kennis van de chemische reacties, die bij de combinatie van geneesmiddelen kunnen plaats vinden en tot gewenste, maar ook tot ongewenste resultaten aanleiding kunnen geven.

Het zal duidelijk zijn, dat een aanzienlijke bekorting van het studieprogramma tot een verandering van de taak van de apotheker zal moeten leiden. In hoeverre een takverdeling in de toekomst onvermijdelijk zal zijn bij het voortschrijden van de wetenschap, is op het ogenblik echter nog niet te zeggen.

Door de grondige theoretische en practische opleiding, speciaal in de analytische scheikunde, wordt bovendien de mogelijkheid geopend tot het innemen van vele andere posities, hetzij ten dienste van de volksgezondheid, hetzij ten dienste van de industrie, hetzij ten dienste van de wetenschap. In Nederland vinden apothekers dan ook in tal van andere functies hun levenstaak, zoals in de inspectie op de volksgezondheid, in ziekenhuizen als apotheker of als klinisch chemicus, in de keuringsdiensten van waren of in de industrie als levensmiddelenscheikundige, in politiedienst als toxicoloog, en zo nog vele meer.

Het beroep van apotheker geeft een mooie, voldoening gevende dagtaak aan mensen, die een grote verantwoordelijkheid kunnen dragen en bereid zijn door hard werken en geregelde studie de maatschappij te dienen. Dit dienen houdt in, dat niet in de eerste plaats de honorering maatgewend moet zijn voor de keuze van de studie voor apotheker. 
Slechts dan zal de apotheker de achting van zijn medeburgers ten volle ten deel vallen, indien deze zijn beroep op ethische motieven gefundeerd uitoefent.

Utrecht,

K. W. GERRITSMA.

Nederland. 